\title{
EVALUASI KEBERHASILAN IMPLEMENTASI SISTEM INFORMASI MANAJEMEN KULIAH KERJA NYATA MENGGUNAKAN METODE HOT FIT
}

\author{
${ }^{1}$ Medyantiwi Rahmawita Munzir, ${ }^{2}$ Nailul Khaira \\ ${ }^{1,2}$ Program Studi Sistem Informasi, Fakultas Sains dan Teknologi UIN Suska Riau \\ J1. HR Soebrantas KM.18 Panam Pekanbaru - Riau \\ Email: $\underline{1 \text { diantiwi0@gmail.com, }{ }^{2} \text { nailul.khaira@students.uin-suska.ac.id }}$
}

\begin{abstract}
ABSTRAK
Sistem Informasi Manajemen Kuliah Kerja Nyata (SIM KKN) digunakan untuk melakukan pendaftaran KKN. Pada penggunaan SIM KKN masih terdapat permasalahan seperti system yang sering mengalami down yang disebabkan oleh server yang kurang lebar, tidak tersimpannya data mahasiswa yang telah mendaftar pada database SIM KKN, dan tidak adanya sosialisasi tentang penggunaan system kepada mahasiswa sebagai pengguna. Maka dilakukan evaluasi denga menggunakan metode HOT FIT. Tujuan penelitian ini yaitu untuk menemukan factor yang signifikan berpengaruh antara faktor manusia, organisasi, dan teknologi yang mempengaruhi keberhasilan implementasi SIM KKN. Untuk teknik analisis data menggunakan SEMPLS dan alat pengolahan data yaitu SMARTPLS 3.0. Hasil dari pengujian hipotesis, dari 12 hipotesis yang diajukan 7 hipotesis diterima dan 5 hipotesis di tolak. Hasil dari penelitian ini menunjukkan bahwa penerapan SIM KKN pada UIN Suska Riau belum sepenuhnya sukses karena masih terdapat tujuan dari penerapan SIM KKN yang belum tercapai. Dalam HOT FIT, keberhasilan implementasi SIM KKN pada UIN Suska Riau berada pada tingkat $54.5 \%$ dan termasuk kategori cukup baik.
\end{abstract}

Kata Kunci: HOT Fit, Keberhasilan Implementasi SIMRS, SEM PLS, SIM KKN

\section{A. PENDAHULUAN}

Kuliah Kerja Nyata (KKN) merupakan kegiatan intrakurikuler yang memberikan kesempatan kepada mahasiswa untuk belajar dan bekerja sama dengan masyarakat. Kuliah Kerja Nyata pada tahun 2018 di ikuti sebanyak 4731 mahasiswa. Adapun persyaratan bagi mahasiswa untuk mengikuti Kuliah Kerja Nyata adalah : 1. Mahasiswa aktif pada semester VI dan telah menyelesaikan minimal 100 SKS, 2. Melakukan pendaftaran secara online di portal Kuliah Kerja Nyata : sip-lppm.uin.suska.ac.id/kkn, 3. Melakukan pemilihan lokasi di portal di atas sesuai dengan waktu yang telah ditetapkan, 4. Sehat jasmani dan rohani. 5. Mengikuti dan dinyatakan lulus kegiatan pembekalan yang dilaksanakan oleh lembaga pengabdian UIN Suska Riau.

Dengan demikian, seluruh mahasiswa yang telah memenuhi persyaratan diatas dapat melakukan pendaftran Kuliah Kerja Nyata secara online pada portal sistem informasi management KKN: sip-lppm.uin.suska.ac.id/kkn. System Informasi Manajemen KKN ini sudah di gunakan semenjak 3 tahun yang lalu tepatnya pada periode KKN tahun 2015.

Namun, dalam menggunakan sistem tersebut dan berdasarkan observasi terhadap mahasiswa yang telah melakukan KKN banyak ditemukan permasalahan dalam pengimplementasian sistem managemen KKN tersebut.
Permasalahan pertama dari sisi teknologi ataupun dari sisi sistem informasi management KKN tersebut adalah sistem sering mengalami kerusakan yang menyebabkan sebagian data mahasiswa yang telah mendaftar sebelumnya hilang. Masalah lainnya adalah keadaan server yang kurang besar yang mengakibatkan server down. Permasalahan kedua mahasiswa merasa dirugikan karena tidak dapat menggunakan system dengan lancar. Dan bagi mahasiswa yang kehilangan data dapat berakibat fatal tidak dapat mengikuti KKN. Permasalahan ketiga tidak adanya sosialisasi penggunaan system dari pihak LPPM kepada mahasiswa. Oleh karena itu, di perlukannya evaluasi terhadap sistem informasi management Kuliah Kerja Nyata : sip-lppm.uin.suska.ac.id.

Evaluasi SIM adalah mendefinisikan seberapa baik SIM dapat beroperasi pada organisasi yang menerapkannya untuk memperbaiki prestasi dimasa mendatang[1]. Evaluasi sistem informasi management Kuliah Kerja Nyata (KKN) menggunakan metode HOT FIT. Dari model - model evaluasi sistem yang diuraikan, HOT FIT model merupakan model yang lengkap dan paling sesuai dengan kondisi permasalahan yang ada di bandingkan dengan model yang lain[2].

Adapun tujuan dari penelitian ini yaitu untuk mendapatkan factor yang paling berpengaruh antara faktor manusia, organisasi, dan teknologi yang mempengaruhi keberhasilan implementasi 


\section{SIM KKN.}

Manfaat yang ingin dicapai dari penelitian ini yaitu dengan mengetahui faktor - faktor keberhasilan implementasi SIM KKN, dapat mengetahui faktor manakah yang paling berpengaruh dalam keberhasilan implementasi SIM KKN pada UIN Suska Riau.

\section{B. LANDASAN TEORI \\ B.1. Pengertian Evaluasi}

Evaluasi berasal dari bahasa inggris yaitu evaluation yang berarti penilaian atau penaksiran. Evaluasi adalah "the process of delineating, obtaining, and providing useful information for judging decision alternatives" artinya evaluasi merupakan proses penggambaran, memperoleh dan menyajikan informasi yang berguna untuk memutuskan suatu alternative keputusan[3]. Tujuan evaluasi adalah mengumpulkan informasi untuk menentukan nilai dan manfaat objek evaluasi, mengontrol, memperbaiki, dan mengambil keputusan mengenai objek tersebut.

\section{B.2. Pengertian Sistem Informasi}

Sistem informasi secara teknis sebagai satuan komponen yang saling berhubungan yang mengumpulkan (atau mendapatkan kembali), meproses, menyimpan, serta mendistribusikan informasi untuk mendukung pengambilan keputusan dan kendali dalam suatu organisasi. Sebagai tambahan terhadap pendukung pengambilan keputusan, koordinasi, dan kendali, sistem informasi dapat juga membantu para manajer dan karyawan untuk meniliti permasalahan, memvisualisasikan pokok - pokok yang komplek, dan menciptakan produk - produk baru [4].

\section{B.3. Human Organization Technology Fit (HOT Fit)}

HOT Fit adalah salah satu kerangka teori yang digunakan untuk mengevaluasi sistem informasi. Model ini awalnya dikembangkan dari penggabungan model kesuksesan sistem informasi Delone dan Mclean dengan IT Organization Fit model yang dikemukakan oleh Scott Morton. Model HOT Fit menjelaskan secara komprehensif berupa interpretasi kompleksitas, hubungan timbal balik antara orang, organisasi, dan teknologi. Metode evaluasi ini memperjelas dalam penelitian berdasarkan kerangka kerja evaluasi HOT Fit mulai dari human, organization dan technology [2].

Variabel yang terdapat pada HOT Fit yaitu :

\section{1) Human}

Komponen manusia menilai sistem informasi dari sisi penggunaan sistem (system use) pada frekuensi dan luasnya fungsi dan penyelidikan sistem informasi. System use juga berhubungan dengan siapa yang menggunakan (who use it), tingkat penggunanya (level of user), pelatihan, pengetahuan, harapan dan sikap menerima (acceptance) atau menolak (resistance) sistem. Komponen ini juga menilai sistem dari aspek kepuasan pengguna (user satisfaction).

\section{2) Organization}

Setelah semua pola frekuensi tinggi Kompoonen organisasi (organization) menilai sistem dari aspek struktur organisasi dan lingkungan organisasi tmpat sistem teknologi informasi diimplementasikan . struktur organisasi terdiri dari tipe, budaya, politik, hirarki, perencanaan dan komunikasi[5]. Kepemimpinan, dukungan dari top manajemen dan dukungan staf merupakan bagian yang penting dalam mengukur keberhasilan sistem. Sedangkan lingkungan organisasi terdiri dari sumber pembiayaan, pemerintahan, politik, kompetisi, hubungan interorganisasional dan komunikasi.

\section{3) Technology}

Komponen teknologi terdiri dari kualitas sistem (system quality), kualitas informasi (information quality) dan kualitas layanan (service quality). Kualitas sistem dalam sistem informasi menyangkut keterkaitan fitur dalam sistem termasuk performa sistem dan user interface. Kemudahan penggunaan (ease of use), kemudahan untuk dipelajari (ease of learning), response time, usefulness, ketersediaan, fleksibilitas, dan sekuritas merupakan variabel atau faktor yang dapat dinilai dari kualitas sistem.

\section{4) Net Benefit}

Kualitas sistem, kualitas informasi dan kualitas layanan dapat mempengaruhi penggunaan sistem dan kepuasan pengguna. Penggunaan sistem berdasarkan pada pengetahuan dan pelatihan pengguna. Fit dapat diukur dan dianalisis menggunakan jumlah defenisi yang diberikan ketiga faktor. Ketiga faktor tersebut berhubungan dengan dimensi dan kesuksesan sistem informasi yaitu system quality, service quality, sistem use, usersatisfaction, structure, environtment, dan net benefit. Model ini dianggap mampu menjelaskan secara komprehensif dengan pendekatan komponen inti sistem informasi yaitu human, organization, dan technology serta kesesuaian ketiga komponen tersebut sangat mempengaruhi manfaat (net benefit) dari penerapan sistem informasi.

\section{B.4. SEM PLS}

Structural Equation Modeling (SEM) adalah teknik statistic multivariate yang merupakan kombinasi antara analisis factor dan analisis rergesi (Korelasi), yang bertujuan untuk menguji hubungan - hubungan antar variable yang ada pada sebuah model, baik itu antar - indicator dengan konstruknya ataupun hubungan antar - konstruk [6].

Menurut Maruyama dalam (Wijaya, 2001) menyebutkan SEM adalah sebuah model statistik yang memberikan perkiraan perhitungan dari kekuatan hubungan hipotesis diantara variabel 
dalam sebuah model teoritis, baik langsung atau melalu variabel antara (intervening or moderating ) [7].

Proses pemodelan SEM terdiri dari dua pemodelan yaitu model struktural dan model measurement. Model struktural merupakan gabungan dari model persamaan simultan diantara variabel laten[8]. Model measurement adalah hubungan (nilai loading) antara indikator dengan konstruk (laten) . SEM mengutamakan pemodelan konfirmasi dibandingkan pemodelan eksploratori sehingga lebih tepat digunakan untuk pengujian teori. SEM juga dimulai dengan pengembangan representasi model serta dapat digunakan untuk pengujian beberapa statistika lanjutan.

\section{METODOLOGI PENELITIAN}

Dalam menyusun penelitian dibutuhkan langkah-langkah untuk menyusun dan menghasilkan sebuah laporan yang terstruktur. Di bawah ini adalah langkah-langkah yang dilakukan dalam penelitian.

\section{C.1. Tahap Pendahuluan}

Pada tahapan pendahuluan ini kegiatan yang dilakukan adalah :

\section{1) Menentukan Tempat Penelitian}

Langkah yang paling pertama dilakukan penulis adalah mencari tempat penelitian untuk melakukan penelitian tugas akhir, disini penulis mendapatkan tempat penelitian yaitu pada LPPM UIN SUSKA RIAU

\section{2) Menentukan Objek Penelitian}

Pada penyusunan laporan tugas akhir ini, hal yang pertama dilakukan adalah menentukan objek penelitian, yang menjadi objek penelitian adalah Sistem Informasi Manajemen Kuliah Kerja Nyata Online UIN SUSKA RIAU.

\section{3) Menentukan Judul Penelitian}

Setelah menentukan objek penelitian, langkah selanjutnya adalah menentukan judul penelitian tugas akhir ini yaitu evaluasi kualitas layanan system informasi manajemen kuliah kerja nyata menggunakan metode hot fit.

\section{C.2. Tahap Perencanaan}

Adapun tahapan dalam perencanaan adalah sebagai berikut:

\section{1) Identifikasi Masalah \\ 2) Menentukan Hipotesis \\ 3) Menentukan Data Yang Dibutuhkan \\ 4) Menentukan Teknik Pengumpulan Data}

\section{C.3. Tahap Pengumpulan Data}

Tahap ini merupakan tahap yang dilakukan setelah tahap perencanaan. Setelah data ditentukan, maka selanjutnya adalah mengumpulkan data tersebut. Tahapan ini berisi tentang proses dalam pengumpulan data, baik data primer maupun data sekunder. Tahapannya adalah sebagai berikut :

\section{1) Studi Pustaka}

Studi pustaka dilakukan untuk mengumpulkan data sekunder, yaitu data yang diperoleh dari data internal objek penelitian, seperti data yang diperoleh dari buku dan jurnal yang berhubungan dengan judul penelitian.

\section{2) Observasi}

Pada tahap ini melakukan pengamatan langsung terhadap system informasi manajemen KKN dengan melihat tampilan system informasi manajemen KKN dan melihat permasalahanpermasalahan yang ada pada system informasi KKN.

\section{3) Wawancara}

Wawancara dilakukan langsung dengan bagian admin dari system informasi $\mathrm{kkn}$ online. Dan mahasiswa UIN Suska angkatan 2015 yang telah mengikuti KKN.

\section{4) Menentukan Responden}

Responden yang dijadikan sampel dalam penelitian ini adalah mahasiswa UIN SUSKA yang telah melaksanakan KKN. Teknik penarikan sampel menggunakan teknik random sampling dengan populasi sebanyak 4731 orang dan kemudian menghitung sample menggunakan rumus slovin. Maka jumlah sampel yang digunakan dalam penelitian ini adalah 100 orang setelah dibulatkan.

\section{5) Menyebar Kuisioner}

Dalam Penelitian ini skala yang akan digunakan adalah skala Likert. Skala ini digunakan untuk mengukur respon subjek ke dalam 4 poin skala dengan interval yang sama.empat kategori yang dapat ditunjukkan pada Tabel 3.1 berikut ini Table 3. Kategori Jawaban menurut Skala

\begin{tabular}{cc}
\hline Kategori & Skala \\
\hline Sangat setuju & 4 \\
Setuju & 3 \\
Tidak setuju & 2 \\
Sangat tidak setuju & 1 \\
\hline
\end{tabular}

\section{C.4. Tahap Pengolahan Data}

Data yang terkumpul lalu diolah. Pertama data di seleksi atas dasar validitas dan reliabilitas. Pengolahan data dilakukan menggunakan analisis statistic dengan tools atau alat berupa aplikasi, yaitu aplikasi SemPLS.Dengan aplikasi ini, dilakukanlah pengujian validitas dan reabilitas data. 1) Uji Validitas

Pada tahapan ini peneliti akan melakukan uji validitas yang bertujuan untuk mengetahui apakah data kuesioner yang kita dapat sudah valid atau tidak. Pengujian dilakukan dengan caramembandingkan nilai korelasi Product Moment atau $\mathrm{R}$ table dengan $\mathrm{R}$ hitung dimana $\mathrm{R}$ hitung harus lebih besar dari $\mathrm{R}$ tabel.

\section{2) Uji Reliabilitas}

Pada tahapan ini peneliti melakukan uji reliabitias yang bertujuan untuk mengetahui apakah data yang penelita peroleh sudah reliable atau non reliable. 


\section{C.5. Tahap Dokumentasi}

Melakukan dokumentasi hasil penelitian yaitu seluruh data yang diperoleh dari serangkaian penelitian yang telah dilakukan akan menghasilkan sebuah laporan yang nantinya akan diujikan kembali kepada pembimbing ataupun penguji penelitian. Data yang didapatkan sebelumnya diolah sedemikian rupa kedalam laporan penelitian yang akhirnya diharapkan dapat memberikan manfaat dalam penelitian ini.

\section{HASIL DAN PEMBAHASAN}

Untuk mengetahui keberhasilan implementasi SIM KKN, peneliti menggunakan 4 konstruk Hot fit yaitu human, organization, technology dan net benefits. Setelah konstruk ditentukan maka di dapatkan hipotesis sebagai berikut:

H1 : kualitas system (System Quality) berpengaruhbpositif terhadap penggunaan system

H2 : kualitas system berpengaruh (System Quality) berpengaruh positif terhadap kepuasaan pengguna (User Satisfaction)

H3 : kualitas informasi (Information Quality) berpengaruh positif terhadap penggunaan system (System use)

H4 : kualitas informasi (Information Quality) berpengaruh positif terhadap kepuasaan pengguna (User Satisfaction)

H5 : kualitas layanan (Service Quality) berpengaruh positif terhadap penggunaan system (System Use)

H6: kualitas layanan berpengaruh positif terhadap kepuassaan pengguna (User Satisfaction)

H7 : kepuasaa pengguna (user satisfaction) berpengaruh positif dan signifikan terhadap penggunaan system (system use)

H8 : struktur organisasi (struktur) berpengaruh positif dan signifikan terhadap lingkungan organisasi (environtment)

H9 : penggunaan system (system use) berpengaruh positif dan signifikan terhadap manfaat (net benefit)

H10: kepuasan pengguna (user satisfaction) berpengaruh positif dan signifikan terhadap manfaat (net benefit)

H11: struktur organisasi berpengaruh positif dan signifikan terhadap manfaat

H12: lingkungan organisasi berpengaruh positif dan signifikan terhadap manfaat.

Karena penelitian ini memiliki sampel yang kecil maka evaluasi model dilakukan dengan menggunakan perangkat lunak yaitu Smart PLS 3.0 yang terdiri dari dua jenis evaluasi yaitu mengevaluasi outer model dan mengevaluasi inner model.

Evaluasi outer model dan inner model di analisis melalui jalur diagram (path diagram) yang telah dirancang sebelumnya dengan menggambarkan hubungan antara variabel terukur dengan variabel laten. Dari hasil path diagram ini nantinya akan didapatkan hasil yang berupa nilai dari evaluasi outer model serta inner model.

Dalam penelitian ini terdapat empat konstruk dengan indikator yang reflektif. Keempat konstruk tersebut yaitu Organisasi (Organization), Human, Teknologi (Technology), dan Net Benefit. Selanjutnya dalam mengevaluasi outer model keempat konstruk tersebut akan ditentukan indikator-indikator yang sesuai dengan jelas, dimana indikator tersebut akan dinilai dengan melihat outer loadings dan discriminant validity dari indikator pembentuk konstruk laten untuk mendapatkan nilai average variance extracted, composite realibility, dan cronbach's alpha

Untuk menguji apakah instrument yang digunakan valid atau tidak, pada dasarnya digunakan korelasi Pearson, dengan ketentuan pengujian apabila rXy lebih besar dari r-tabel atau r-kritis, maka data tersebut valid. Namun apabila $r$ hitung (rXy) lebih kecil dari r-tabel (r-kritis), maka data tersebut tersebut tidak valid. Atau dalam keterangan lain ukuran reflesif individual dikatakan tinggi apabila berkorelasi lebih dari 0.70 dengan variable atau konstruk yang ingin diukur. Namun untuk penelitian tahap awal dari pengembangan skala pengukuran nilai loading 0.5 sampai 0.6 dianggap cukup.(cin, dikutip oleh Ghazali, 2014)

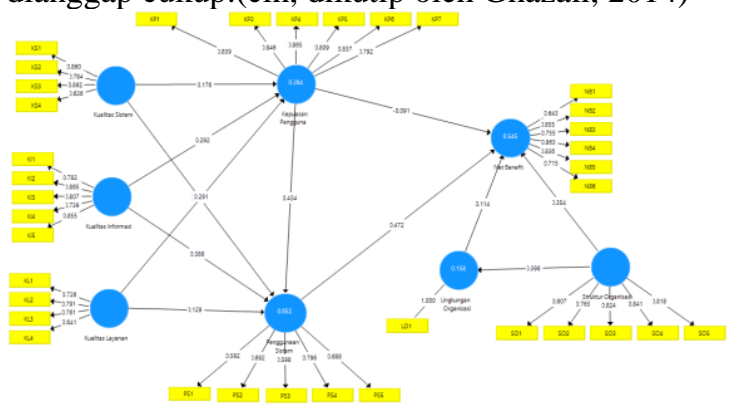

\section{Gambar 1. Nilai Convergent Validity}

Langkah selanjutnya untuk menentukan nilai outer model adalah dengan perhitungan discriminant validity dengan cara mengukur berdasarkan nilai cross loadings yang nantinya nilai tersebut untuk mendapatkan nilai average variance extracted, composite realibility, dan cronbach's alpha.

Tabel 2. Nilai Discriminant Variabel Validity Cross Loading

\begin{tabular}{|l|l|l|l|l|l|l|l|l|}
\hline & KP & KI & KL & KS & LO & NB & PS & SO \\
\hline KI1 & 0.372 & 0.782 & 0.425 & 0.409 & 0.314 & 0.455 & 0.539 & 0.447 \\
\hline KI2 & 0.455 & 0.865 & 0.296 & 0.422 & 0.474 & 0.505 & 0.602 & 0.519 \\
\hline KI3 & 0.367 & 0.807 & 0.292 & 0.324 & 0.326 & 0.341 & 0.488 & 0.386 \\
\hline
\end{tabular}


Jurnal Ilmiah Rekayasa dan Manajemen Sistem Informasi, Vol. 6, No. 1, Februari 2020, Hal. 100-108

e-ISSN 2502-8995 p-ISSN 2460-8181






\begin{tabular}{ll}
\hline $\begin{array}{l}\text { Lingkungan } \\
\text { Organisasi }\end{array}$ & 1.000 \\
\hline Net Benefit & 0.903 \\
\hline Penggunaan Sistem & 0.807 \\
\hline Struktur Organisasi & 0.881 \\
\hline
\end{tabular}

Hasil diatas menunjukkan bahwa nilai composite reliability dari setiap konstruk lebih besar dari 0.60, dari hasil tersebut dapat dibuktikan bahwa semua nilai konstruk reliable.

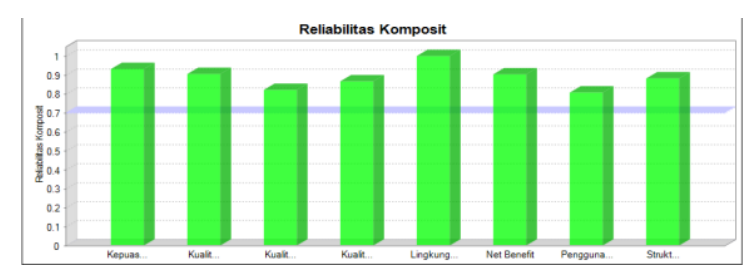

\section{Gambar 3. Diagram Composite Reliability}

Dalam pengujian inner model terdapat dua tahap pengujian yaitu pengujian kelayakan model dan pengujian signifikan jalur. Pengujian inner model ini bertujuan untuk menggambarkan hubungan antar variabel laten. Untuk melihat dan menilai uji inner model dimulai dengan melihat $\mathrm{R}$ Square yang berfungsi untuk melihat seberapa besar kontribusi pengaruh yang diberikan oleh setiap variabel. Menurut, nilai R Square 0.70 , $0.50,0.25$ dapat dikatan bahwa model tersebut kuat, moderate dan lemah.

Tabel 4. Cronbach's Alpha

\begin{tabular}{ll}
\hline & $\begin{array}{l}\text { Cronbach's } \\
\text { Alpha }\end{array}$ \\
\hline Kepuasan Pengguna & 0.364 \\
$\begin{array}{l}\text { Lingkungan } \\
\text { Organisasi }\end{array}$ & 0.158 \\
Net Benefit & 0.545 \\
\hline Penggunaan Sistem & 0.652 \\
\hline
\end{tabular}

Dari hasil nilai R-Square dapat dilihat bahwa variable yang memiliki pengaruh yang paling pokok dari model yang dianalisis terdapat pada variable penggunaan system dengan nilai 0.652 , variable net benefit dengan nilai 0.545 , variable kepuassaan pengguna 0.364, dan variable lingkungan organisasi 0.158. Dengan demikian dapat dikatakan bahwa model tersebut moderate.

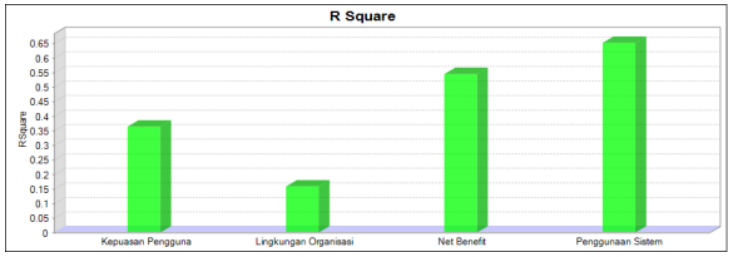

Gambar 4. Diagram R-Square

Dalam menentukan pengujian hipotesis diperlukan melihat nilai yang terdapat pada output path coefficient. Pengujian yang dilakukan menggunakan PLS memberikan nilai estimasi untuk pengujian secara statistik setiap hubungan yang akan dihipotesiskan.

Tabel 5. Nilai Path Coeffecients ( Mean, Stdev, T-Values)

\begin{tabular}{|c|c|c|c|c|}
\hline & $\begin{array}{l}\text { Original } \\
\text { Sampel } \\
\text { (O) }\end{array}$ & $\begin{array}{l}\text { Sampel } \\
\text { Mean } \\
(\mathrm{M})\end{array}$ & $\begin{array}{l}\text { Standart } \\
\text { Deviation } \\
\text { (STDEV) }\end{array}$ & $\begin{array}{l}\text { T Statistic } \\
( \\
|\mathrm{O} / \mathrm{STDEV}|)\end{array}$ \\
\hline $\begin{array}{l}\mathrm{KP} \\
\rightarrow \mathrm{NB}\end{array}$ & -0.091 & -0.093 & 0.117 & 0.776 \\
\hline $\begin{array}{ll}\mathrm{KP} & \rightarrow \\
\mathrm{PS} & \end{array}$ & 0.434 & 0.426 & 0.083 & 5.213 \\
\hline $\begin{array}{ll}\mathrm{KI} & \rightarrow \\
\mathrm{KP} & \end{array}$ & 0.292 & 0.279 & 0.097 & 3.028 \\
\hline $\begin{array}{ll}\mathrm{KI} & \rightarrow \\
\mathrm{PS} & \end{array}$ & 0.388 & 0.382 & 0.082 & 4.699 \\
\hline $\begin{array}{l}\mathrm{KL} \rightarrow \\
\mathrm{KP}\end{array}$ & 0.291 & 0.303 & 0.104 & 2.790 \\
\hline $\begin{array}{l}\mathrm{KL} \rightarrow \\
\mathrm{PS}\end{array}$ & 0.129 & 0.138 & 0.079 & 1.623 \\
\hline $\begin{array}{ll}\mathrm{KS} & \rightarrow \\
\mathrm{KP} & \end{array}$ & 0.176 & 0.185 & 0.112 & 1.566 \\
\hline $\begin{array}{ll}\mathrm{KS} & \rightarrow \\
\mathrm{PS} & \end{array}$ & 0.035 & 0.040 & 0.077 & 0.456 \\
\hline $\begin{array}{ll}\mathrm{LO} & \rightarrow \\
\mathrm{NB} & \end{array}$ & 0.114 & 0.112 & 0.078 & 1.469 \\
\hline $\begin{array}{ll}\mathrm{PS} & \rightarrow \\
\mathrm{NB} & \end{array}$ & 0.472 & 0.485 & 0.131 & 3.609 \\
\hline $\begin{array}{l}\mathrm{SO} \rightarrow \\
\mathrm{LO}\end{array}$ & 0.398 & 0.397 & 0.102 & 3.900 \\
\hline $\begin{array}{ll}\mathrm{SO} & \rightarrow \\
\mathrm{NB} & \end{array}$ & 0.354 & 0.349 & 0.124 & 2.856 \\
\hline
\end{tabular}


1) Kepuasan Pengguna Berpengaruh terhadap Net Benefit

nilai $\mathrm{t}$ sebesar 0.776 dimana hasil ini lebih kecil dari t tabel (1.96).Kepuasaan pengguna tidak berpengaruh terhadap net benefit disebabkan karena masih banyak nya kekurangan pada SIM KKN seperti fitur - fitur nya yang belum sesuai dengan kebutuhan, seperti belum bisanya melihat nilai pada aplikasi SIM KKN. Selain itu informasi yang dihasilkan kurang akurat seperti pada saat pemilihan desa, ketika mahasiswa memilih suatu desa, namun desa yang berhasil dipilih berbeda dengan desa pada saat pemilihan, serta sering nya system mengatakan suatu desa sudah terisi penuh namun pada list nama hanya berisi 5 orang saja sementara kapasitas suatu desa tersebut $10-15$ orang

\section{2) Kepuasan Pengguna Berpengaruh Terhadap Penggunaan Sistem \\ nilai t sebesar 5.213. nilai tersebut lebih besar} dari $t$ tabel (1.96). Kedua variable tersebut saling berpengaruh disebabkan oleh penggunaan system yang mempermudah mahasiswa dalam proses pencarian lokasi KKN serta system yang digunakan mudah untuk dipahami sehingga mahasiswa merasa puas dalam menggunakan SIM KKN. Serta dengan adanya SIM KKN ini mempermudah mahasiswa dalam mencari informasi seperti anggota kelompok KKN dan nomor telepon yang bisa dihubungi untuk membicarakan segala hal terkait pelaksanaan KKN.

3) Kualitas Informasi Berpengaruh Terhadap Kepuasan Pengguna

nilai t sebesar 3.028. Hasil ini menunjukkan

bahwa kualitas informasi mempengaruhi penggunaan system. Pengaruh yang baik ini disebabkan karena kualitas informasi yang baik dan benar dan juga bisa di pertanggung jawabkan mempunyai pengaruh langsung terhadap kepuasaan pengguna. Seperti adanya data mengenai anggota kelompok dan dosen pembimbing lapangan yang tersimpan di dalam SIM KKN.

4) Kualitas Informasi Berpengaruh Terhadap Penggunaan Sistem

nilai t sebesar 4.699. Nilai tersebut lebih besar dari pada $t$ tabel (1.96). Kedua indikator saling mempengaruhi disebabkan oleh informasi yang dihasilkan sesuai dengan kenyataan tepat dan akurat serta mudah untuk di baca dan di pahami mengakibatkan intensitas pengguna system menjadi lebih tinggi lagi, terlebih pada saat pemilihan lokasi KKN yang mana nama - nama lokasi KKN seluruh nyaa tertera pada system ini mulai dari kabupaten / kota, kecamatan, serta desa tempat mahasiswa yang bersangkutan melaksankan KKN.
5) Kualitas Layanan Berpengaruh terhadap Kepuasan Pengguna

nilai t sebesar 2.790. Nilai tersebut lebih besar dari pada $\mathrm{t}$ tabel (1.96). Yang artinya kualitas layanan yang diberikan oleh LPPM baik yang menghasilkan kepuasaan pengguna bagi setiap mahasiswa yang menggunakan system informasi manajemen KKN. Semakin bagus kualitas layanan yang diberikan maka mahasiswa semakin mudah menggunakan system dan akan merasakan suatu kepuasan pengguna.

6) Kualitas Layanan Berpengaruh terhadap Penggunaan Sistem

nilai $\mathrm{t}$ sebesar 1.623 dimana hasil ini lebih kecil dari t tabel (1.96). Kualitas layanan tidak berpengaruh terhadap penggunaan system disebabkan karena tidak adanya sosialisasi penggunaan system dari LPPM untuk mahasiswa yang menggunakan SIM KKN. Hal ini menyebabkan mahasiswa kurang memahami bagaimana penggunaan system SIM KKN. Untuk mahasiswa yang tidak memahami SIM KKN menyebabkan mereka meminta pertolongan kepada temannya untuk mengisikan data - data pribadi mereka, hal tersebut menyebabkan banyak nyaa terjadi kesalahan dalam pengisian data, dan pemilihan lokasi.

7) Kualitas Sistem Berpengaruh Terhadap Kepuasan Pengguna

nilai $\mathrm{t}$ sebesar 1.566 dimana hasil ini lebih kecil dari $\mathrm{t}$ tabel (1.96).Kualitas system tidak berpengaruh terhadap kepuasan pengguna hal ini disebabkan oleh system informasi manajemen KKN yang sering mengalami error sehingga pengguna dari system ini tidak puas dalam menggunakan system tersebut. Selain itu system juga susah di akses dari manapun. System mudah digunakan hanya pada lingkungan kampus, sementara untuk wilayah yang jauh system sering mengalami error. Hal ini disebabkan oleh server dari system informasi manajemen KKN yang kurang besar, yang menyebabkan server down ketika di serang oleh banyak pengguna dalam satu waktu.

8) Kualitas Sistem Berpengaruh Terhadap Penggunaan Sistem

nilai $\mathrm{t}$ sebesar 0.456 dimana hasil ini lebih kecil dari $\mathrm{t}$ tabel (1.96).Kualitas system tidak berpengaruh terhadap penggunaan system di sebabkan oleh server yang sering tumbang menyebabkan kualitas system menjadi buruk. Dengan buruk nya kualitas system tersebut, banyak mahasiswa yang tidak dapat menggunakan system pada waktu - waktu tertentu. Hal ini menyebabkan penggunaan system jadi terbatas. Dengan keterbatasan penggunaan system maka mahasiswa merasa dirugikan dan penggunaan system menjadi tidak efektif. 
9) Lingkungan Organisasi Berpengaruh

Terhadap Net Benefit

nilai $\mathrm{t}$ sebesar 1.469 dimana hasil ini lebih kecil dari t tabel (1.96). Lingkungan organisasi tidak berpengaruh terhadap net benefit disebabkan karena tidak setiap pegawai LPPM memahami SIM KKN. Pada saat terjadi nya permasalahan ketika mahasiswa dating untuk menanyakan permasalahannnya hanya admin saja yang bisa menanggulangi permasalahan mahasiswa tersebut. Admin hanya terdiri dari satu orang saja, dan untuk menyelesaikan masalah, mahasiswa harus mengantri untuk menemui admin, sementara pegawai LPPM yang lainnya tidak dapat membantu admin untuk menyelesaikan permasalahan dikarenakan tidak memahami SIM KKN. Penyelesaian masalah seperti ini tidak efektif untuk mencapai keberhasilan implementasi karena memakan waktu yang lama.

\section{0) Penggunaan Sistem Berpengaruh} Terhadap Net Benefit

nilai t sebesar 3.609. Nilai tersebut lebih besar dari pada t tabel (1.96) sehingga penggunaan sistem berpengaruh terhadap net benefit, Yang artinya penggunaan system memiliki pengaruh positif dan signifikan terhadap keberhasilan implementasi SIM KKN. Penggunaan system yang efektif akan mengurangi kesalaha, dengan berkurang nya kesalahan akan mudah untuk mencapai tujuan dengan efektif, dan dengan tercapai nya tujuan dengan efektif akan menghasilkan keberhasilan implementasi SIM KKN.

11) Struktur Organisasi Berpengaruh Terhadap Lingkungan Organisasi

nilai t sebesar 3.900. Nilai tersebut lebih besar dari pada $\mathrm{t}$ tabel (1.96). Yang artinya struktur organisasi mempunyai pengaruh positif dan signifikan terhadap lingkungan organisasi. Hal ini disebabkan oleh semakin teraturnya bagian dan struktur dari organisasi maka akan tercipta lingkungan organisasi yang kondusif. Dengan lingkungan organisasi yang kondusif makan akan meningkatkan keberhasilan implementasi SIM KKN.

12) Struktur Organisasi Berpengaruh Terhadap Net Benefit

nilai t sebesar 2.856. Nilai tersebut lebih besar dari pada $\mathrm{t}$ tabel (1.96). Yang artinya struktur organisasi memiliki pengaruh positif dan signifikan terhadap keberhasilan implementasi. Hal ini disebakan oleh semakin bagusnya pelayanan yang diberikan oleh organisasi terhadap pengguna, dan semakin mendukungnya organisasi dengan memberikan fasilitas - fasilitas yang memadai maka akan tercapainya keberhasilan implementasi dengan efektif dan efisien.

\section{E. KESIMPULAN}

Keberhasilan implementasi Sistem Informasi Manajemen Kuliah kerja Nyata UIN Suska Riau kurang sukses karena masih terdapat kendalam tujuan dari penerapan SIM KKN yang belum memenuhi harapan, yaitu SIM KKN belum memberikan manfaat dalam penerapannya. Dalam HOT FIT, keberhasilan implementasi SIM KKN berada pada tingkat $54.5 \%$ dan termasuk dalam kategori moderate. Nilai diperoleh dari pengujian statistic R-Square variable net benefit yaitu 0.545 .

Pada Faktor manusia, variable kepuasaan pengguna signifikan terhadap penggunaan system, penggunaan system signifikan terhadap net benefit yang di dapat, tetapi kepuasaan pengguna tidak signifikan terhadap net benefit yang didapatkan. Pada factor organisasi variable organisasi signifikan terhadap net benefit dan lingkungan organisasi, sedangkan lingkungan orgaisasi tidak signifikan terhadap net benefit. Pada factor teknologi variable kualitas system tidak signifikan terhadap penggunaan system, kualitas layanan tidak signifikan terhadap penggunaan system, sedangkan kualitas informasi signifikan terhadap penggunaan system. Variable kualitas system tidak signifikan terhadap kepuasaan pengguna, sedangkan kualitas layanan dan kualitas informasi signifikan terhadap kepuasaan pengguna.

\section{REFERENSI}

[1] Diantono, P., \& Winarno, W.W.(2018).Evaluasi Penerapan SIMRS Menggunakan Metode HOT-FIT di RSUD Dr.Soedirman Kebumen, 2(1), 45-46

[2] Krisbiantoro, Dwi., Suyanto, M., Dan Taufiqluthfi, Emha.2015. Evaluasi Keberhasilan Implementasi Sistem Informasi Dengan Pendekatan HOT-FIT Model

[3] Stufflebem, Daniel L., dan Anthony J.Shinkfield.2008. Systematic Evaluation : A Self - Instructionel Guide to Theory and Practice. Boston : Kluwer - Nijhoff Publishing.

[4] Laudon, Kenneth C., dan Jane P. Laudon, (2012). Management System : Managing The Digital Firm Twelfth Edition. New Jersey : Prentice Hall

[5] Erimalata, Shofana.2016. Pendekatan Hot Fit Framework Dalam Generalized Structural Component Analysis Pada Sistem Informasi Manajemen Barang Milik Daerah: Sebuah Pengujian Efek Resprokal

[6] Sari, M.M., Sanjaya, G.Y., \& Meliala, A. (2016). Evaluasi Sistem Informasi Manajemen Rumah Sakit (SIMRS) Dengan Kerangka HOT-FIT. Seminar Nasional Teknologi Informasi Indonesia,( 1 November 2016), 1-6.

[7] Wijayanti, Pritha S., Ispriyanti, D Dan Waryandani, T.2013. Pengambilan Sampel 
Jurnal Ilmiah Rekayasa dan Manajemen Sistem Informasi, Vol. 6, No. 1, Februari 2020, Hal. 100-108 e-ISSN 2502-8995 p-ISSN 2460-8181

Berdasarkan Peringkat Pada Analisis Regresi Linear Sederhana

[8] Haryono, Siswoyo.2014. Mengenal Metode Structural Equation Modelling (SEM) Untuk Penelitian Manajemen Menggunakan Amos 18.00 